Journal of Advanced Research in Fluid Mechanics and Thermal Sciences

Journal homepage: www.akademiabaru.com/arfmts.html ISSN: 2289-7879

\title{
Performance Enhancement of Split Air Conditioner During Evaporative Cooling Application
}

\author{
Rahmat Iman Mainil ${ }^{1,}{ }^{*}$, Ahmad Wisnu Sulaiman ${ }^{1}$, Afdhal Kurniawan Mainil2 $^{2}$, Azridjal Aziz ${ }^{1}$ \\ Department of Mechanical Engineering, Faculty of Engineering, Universitas Riau, Jl. Subrantas km 12.5, Pekanbaru 28293, Riau, Indonesia \\ 2 Department of Mechanical Engineering, Faculty of Engineering, Universitas Bengkulu, J. WR. Supratman, Kandang Limun, Bengkulu 38371A, \\ Indonesia
}

\begin{tabular}{ll} 
ARTICLE INFO & ABSTRACT \\
\hline $\begin{array}{l}\text { Article history: } \\
\text { Received 7 April } 2021 \\
\text { Received in revised form 26 July 2021 }\end{array}$ & $\begin{array}{l}\text { The increase of condenser temperature and pressure in air-conditioning leads to } \\
\text { decreased cooling capacity and the increase of power consumption. Evaporative } \\
\text { cccepted } 30 \text { July } 2021\end{array}$ \\
$\begin{array}{l}\text { cooling could improve the thermal performance of the system. In this study, the } \\
\text { evaporative cooling module was installed before the condenser to reduce the inlet air } \\
\text { temperature to the condenser unit. The impact of condenser air temperature on the } \\
\text { air conditioning system's overall performance was determined by varying the cooling } \\
\text { pad discharge water flowrate of } 880,1040, \text { and } 1200 \text { mL/min. The cooling load of } 2000 \\
\text { W was employed in this experiment. The obtained results were compared with the air } \\
\text { conditioning without an evaporative cooling module. It shows that the coefficient of } \\
\text { performance (COP) increases with the increase of discharge water flow rate. The } \\
\text { highest COP obtained is } 7.09 \text { at the flow rate of } 1200 \mathrm{~mL} / \text { min. The compressor work } \\
\text { reduces about } 6.57 \% \text { as compared with the air conditioner without evaporative } \\
\text { cooling application. Besides, the COP increases by } 12.95 \% \text { at the highest flow rate. }\end{array}$ \\
$\begin{array}{l}\text { Keywords: } \\
\text { Air conditioning system; evaporative } \\
\text { cooling; COP }\end{array}$
\end{tabular}

\section{Introduction}

Air conditioning system is widely used for providing thermal comfort in many domestic and commercial applications. The improvement of living standards and demand for human comfort has caused an increase in energy consumption associated with a higher level of $\mathrm{CO} 2$ emissions. Air conditioning applications' amount of energy occupies $30 \%$ of total world energy consumption[1,2]. Therefore, a continuous energy-saving effort from cooling systems will contribute to worldwide energy efficiency [3-6]. Reduction of energy used for air conditioning units can be made by reducing compressor power consumption, increasing condenser heat rejection capacity, and lowering the condenser and evaporator pressure difference [6-9].

In small-size residential air conditioners such as split-type air conditioners, air condenser performance drops down during the vapor compression cycle due to the increase of condensing temperature. It increases the pressure ratio across the compressor; thus, the compressor work

\footnotetext{
* Corresponding author.

E-mail address: Rahmat.iman@lecturer.unri.ac.id
}

https://doi.org/10.37934/arfmts.86.2.147156 
increases, leading to more power consumption[10-12]. It is well known that when the temperature of condenser increases at each ${ }^{\circ} \mathrm{C}$, the coefficient of performance (COP) of the refrigeration system decreases around 2-4 \% [13]. Using the evaporative cooling (EC) to cool the air around condenser exhibit to be a good way. The water absorbs latent heat during evaporation, which causes the temperature of ambient air drop before passing through the condenser coil [14-17]. Some experimental investigation has been carried out to produce a practical approach to improving air vapor compression systems' performance by evaporative cooling. Broadly, evaporative cooling can be divided into direct evaporative cooling (DEC), indirect evaporative cooling (IEC), and hybrid system which combines direct and indirect evaporative cooling[18].

Harby et al., [19] evaluated the improvement of vapor compression system performance by using an evaporative condenser. It is showed that the energy consumption reduced around $58 \%$ while performance enhanced by $113.4 \%$. The spray evaporative cooling application into an air-cooled chiller has been carried out by Yang et al., [20]. This method reduced the compressor power and enhanced the COP by $4 \%-8 \%$. The review of direct injection water into the air stream using a pump and nozzles has been reported by Ulpiani [21]. The water spray eventually evaporated and decreased the air stream temperature.

The study of direct evaporative cooling coupled with condenser for enhancing cooling capacity and energy saving of window air conditioner with $5.27 \mathrm{~kW}$ cooling capacity has been carried out by hajidavallo [22]. The results showed that the power consumption reduces by $16 \%$ and COP increases about $55 \%$. The effect of ambient air temperatures $\left(35^{\circ} \mathrm{C}\right.$ until $49{ }^{\circ} \mathrm{C}$ )on the performance of air conditioning was studied by Hajidavallo and Eghtedari [23]. The COP increased by $50 \%$ and energy saved by $20 \%$. Pangsakorn and Thepa [24] evaluated the performance of $3.5 \mathrm{~kW}$ inverter air conditioning coupled with an evaporative cooling pad. Results indicated that COP increased by $18 \%$, and power consumption decreased by $35 \%$ compared to the conventional cooling system. Wang et al., [25] experimented with an evaporative cooling condenser of an air conditioning system with a cooling capacity of $7 \mathrm{~kW}$. The enhancement of COP to up to $18 \%$ was achieved, and power consumption decrease to $14.3 \%$. Another study performed an experiment to improve the performance of an air conditioning system ( $7 \mathrm{~kW}$ of cooling capacity) by direct evaporative cooling in extremely hot weather $\left(55^{\circ} \mathrm{C}\right)$ [16]. The study of the effect of cooling pad thickness on the energysaving for air conditioning system was conducted by Harby and Al-amri [26] and Martinez et al., [17]. Results indicated that using an optimum cooling pad thickness of $100 \mathrm{~mm}$ could increase energy saving. Several research groups carried out other studies about implementing condensate discharge of air conditioners to the evaporative cooling system[27-30].

The above review literature indicated the thermal performance improvement of air conditioning system combined with an evaporatively cooled air condenser. Despite the extensive application of evaporative cooling in the air conditioning system's high cooling capacity, the investigation of the lower cooling capacity of the air conditioner is still limited. It should be noticed that the fast-growing split air conditioning in the market encourages many works in the area of air conditioning performance improvement by the evaporative cooling application. Besides, there are still many questions about the performance enhancement affected by the water discharge flow rate of the cooling pad.

Unlike other studies, split air conditioner performance with low cooling capacity of $2.6 \mathrm{~kW}$ coupled with evaporative cooling was examined herein. Also, the air conditioner's evaporative cooling system's performance was compared with the air conditioner's performance without the evaporative cooling module. This experiment was objected to study the effect of evaporative cooler water flow rates on split air conditioning system performance at a maintained cooling load of $2000 \mathrm{~W}$. 


\section{Methodology}

\subsection{Experimental Method}

The experiments were conducted using a split type air conditioner (compressor power of 0.68 $\mathrm{kW}$, the cooling capacity of $2.6 \mathrm{~kW}$ ) which was operated using HCR-22 refrigerant as working fluid. The refrigerant consisted of $99.7 \%$ of propane, $0.15 \%$ of butane, and $0.15 \%$ of isobutane[31,32]. An evaporative cooling system was added as an extension to the AC system. The detailed experimental apparatus is shown in Figure 1.

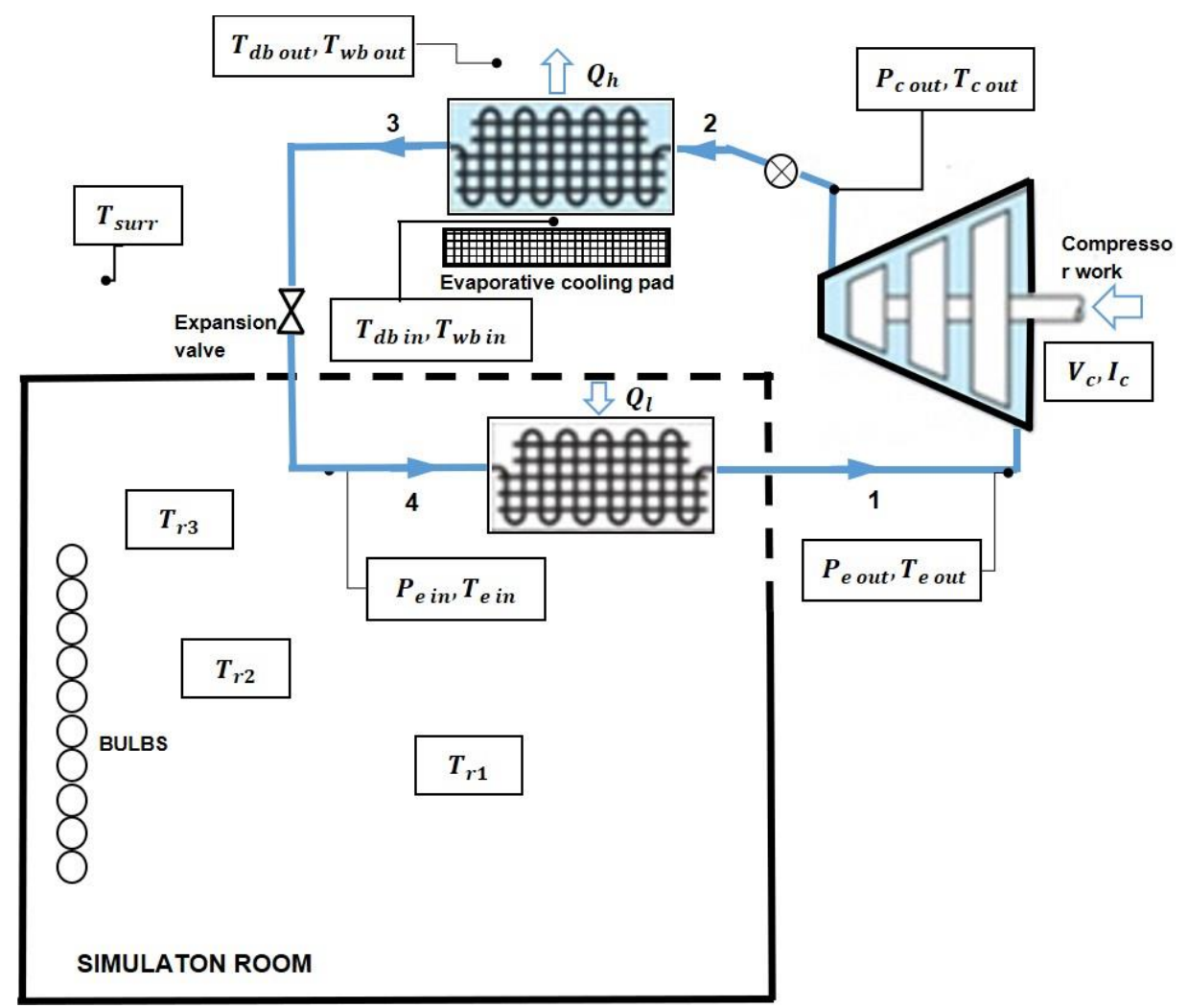

Fig. 1. Schematic of Air conditioning with evaporative cooling module [33]

The $\mathrm{K}$ types thermocouples and data acquisition module (accuracy $0.2 \% \pm 0.5^{\circ} \mathrm{C}$ and resolution $0.1{ }^{\circ} \mathrm{C}$ ) are used to measure temperatures. The refrigerant pressures are determined by analog pressure gauge (accuracy \pm 5 psi for high pressure and \pm 1 psi for low pressure). A digital multimeter (Hioki DT4211) measured the voltage input (accuracy $\pm 1.0 \%$ and 3 digits and current input) and electric current input (accuracy $\pm 2.0 \%$ and 3 digits).

The experiments were divided into two experimental sections. Firstly, the experiment of the air conditioner without evaporative cooling ( $A C$ without $E C$ ), secondly, the experiment of the air conditioner with evaporative cooling ( $A C$ with $E C$ ). To begin $A C$ without EC experiment, the temperature of the cooling room was set at $16^{\circ} \mathrm{C}$. Variation of cooling loads 0 and $2000 \mathrm{~W}$ were modulated in the test room. Then, the pressures, temperatures, and power inputs were recorded. The data was taken every 5 minutes during 120 minutes of experimental run. Similarly, the room temperature was set at $16{ }^{\circ} \mathrm{C}$ when the experiment of AC with EC was started. A cooling load of 2000 $W$ was maintained during the test. Additionally, Wet bulb temperatures and dry bulb temperature of condenser air stream were measured to determine the heat transfer during water vaporization. The water flow rates were adjusted by rotating the ball vale of evaporative cooling equipment. All temperatures, refrigerant pressures, and compressor powers were taken every 5 minutes during 120 
minutes of experimental run. The procedure was repeated by adjusting flow rates of 880,1040 , and $1200 \mathrm{~mL} / \mathrm{min}$. The flow rates changed by modulating the ball valve opening. The temperature of cooling water was the ambient temperature and pressure was the atmospheric pressure. The schematic diagram of the evaporative cooling combined with condenser is presented in Figure 2 . The detail of measurement variables are as follows

i. Evaporator outlet temperature $\left(\mathrm{T}_{\mathrm{e} \text { out }}\right)$

ii. Compressor outlet temperature $\left(\mathrm{T}_{\mathrm{c} \text { out }}\right)$

iii. Evaporator inlet temperature $\left(\mathrm{T}_{\mathrm{e} \text { in }}\right)$

iv. Test room temperature $\left(\mathrm{T}_{\mathrm{r} 1}\right)$

v. Test room temperature $\left(\mathrm{T}_{\mathrm{r} 2}\right)$

vi. Test room temperature $\left(\mathrm{T}_{\mathrm{r} 3}\right)$

vii. Surrounding temperature $\left(\mathrm{T}_{\text {surr }}\right)$

viii. Dry bulb temperature of condenser air inlet $\left(\mathrm{T}_{\mathrm{db}}\right.$ in $)$

ix. Wet bulb temperature of condenser air inlet $\left(\mathrm{T}_{\mathrm{wb}}\right.$ in $)$

$\mathrm{x}$. Dry bulb temperature of condenser outlet $\left(\mathrm{T}_{\mathrm{db} \text { out }}\right)$

xi. Wet bulb temperature of condenser outlet, $\left(\mathrm{T}_{\mathrm{wb} \text { out }}\right)$

xii. Evaporator outlet pressure $\left(\mathrm{P}_{\mathrm{e} \text { out }}\right)$

xiii. Compressor outlet pressure $\left(\mathrm{P}_{\mathrm{c} \text { out }}\right)$

xiv. Evaporator inlet pressure $\left(\mathrm{P}_{\mathrm{e} \text { in }}\right)$

$\mathrm{xv}$. Electric current of compressor $\left(\mathrm{I}_{\mathrm{c}}\right)$

$\mathrm{xvi}$. Electric voltage of compressor $\left(\mathrm{V}_{\mathrm{c}}\right)$

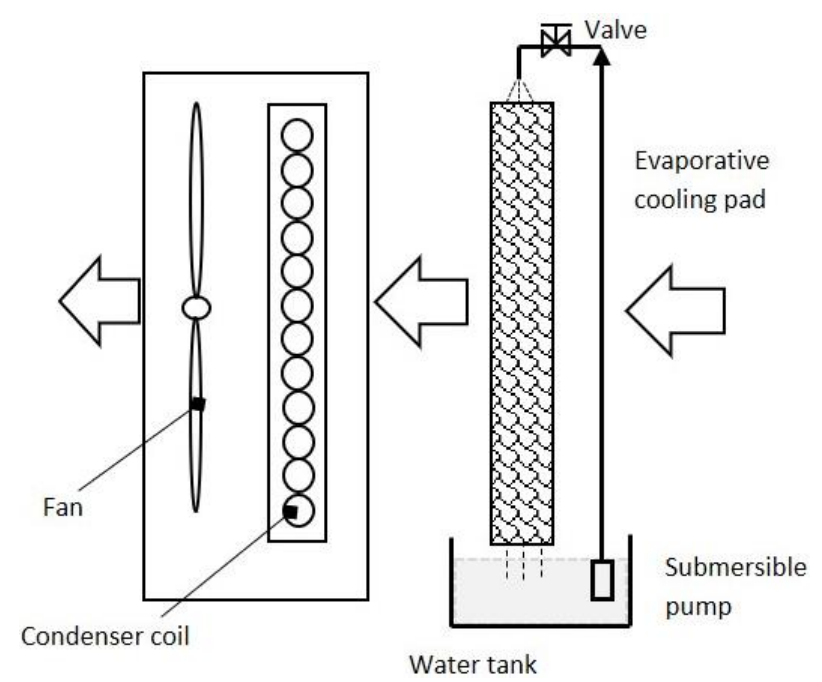

Fig. 2. Schematic diagram of the evaporative cooling combined with a condenser

\subsection{Data Reductions}

The calculation is conducted with assumption of ideal vapor compression cycle, where enthalphy was obtained based on condenser and evaporator pressure. The thermophysical properties of refrigerant is obtained from REFPROP ver. 9.

The compressor power is calculated by Eq. (1).

$W_{\text {net }}=V_{c} \times I_{c} \times \operatorname{Cos} \emptyset$ 
where $W_{\text {net }}$ is the compressor power consumption, $V_{c}$ is voltage, $I_{c}$ is current, and $\operatorname{Cos} \emptyset$ is the power factor of electricity which is 0.83 . The mass flow rate of HCR-22 refrigerant is calculation by Eq. (2).

$$
\dot{m}=\frac{W_{n e t}}{h_{2}-h_{1}}
$$

where $\dot{m}$ is the mass flowrate of refrigerants, $h_{2}$ is enthalphy of refrigerant at compressor exit, and $h_{1}$ is enthalphy of refrigerant at evaporator outlet. The cooling capacity was obtained by Eq. (3).

$Q_{l}=\dot{m}\left(h_{1}-h_{4}\right)$

where $Q_{l}$ cooling capacity of vapor compression system, $h_{1}$ and $h_{4}$ are enthalpy at the outlet and inlet line of evaporator, respectively. The heat rejection capacity is calculated by Eq. (4).

$Q_{h}=\dot{m}\left(h_{2}-h_{3}\right)$

where $Q_{h}$ is heat rejection capacity, $h_{2}$ is enthalphy at outlet of compressor, and $h_{3}$ is enthalphy exit of condenser. To examine the performance of refrigeration system $\left(C O P_{R}\right)$, the Eq. (5) is employed.

$C O P_{R}=\frac{Q_{l}}{W_{n e t}}$

\section{Results}

3.1 Effect of Evaporative Cooling Water Flow Rate on Inlet and Outlet Air Temperature of the Condenser

The effect of cooling water flow rates on the inlet and outlet air stream temperature in the condenser is shown in Figure 3. The condenser's inlet and outlet temperatures were examined at a fixed cooling load of $2000 \mathrm{~W}$.

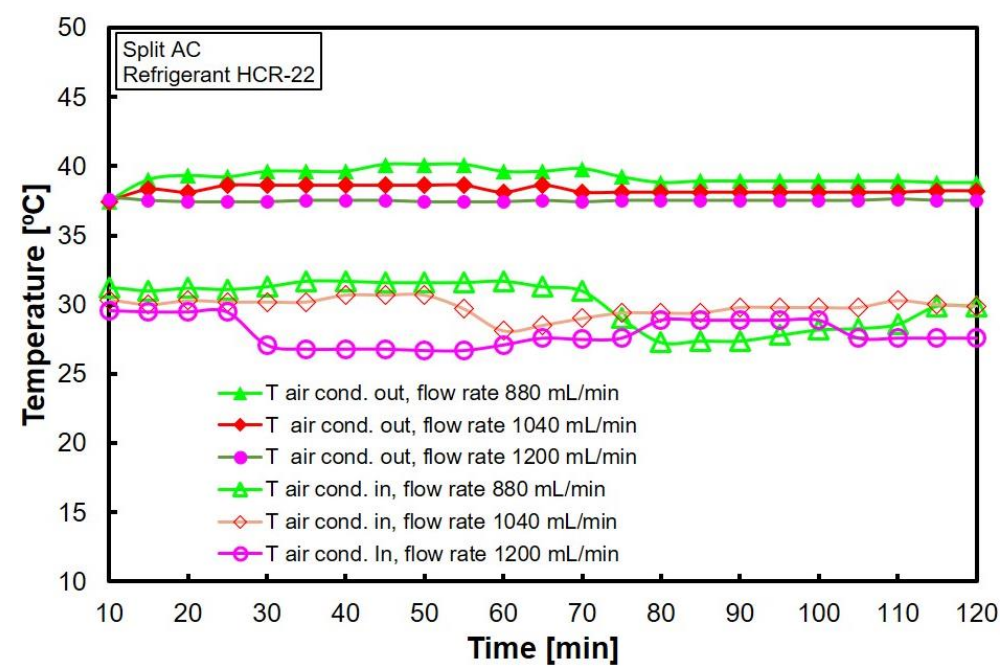

Fig. 3. Air stream temperatures of condenser at a variation of flow rate during experiments 
As seen in Figure 3, the use of evaporative cooling causes the temperature of air entering the condenser drops below ambient temperature. The higher cooling water flow rate resulted in the lower inlet and outlet condenser temperature. During the evaporation of water, the phase of water changed from liquid to vapor. As a consequence, the highest-energy particles leave the water, resulting in a temperature drop. Thus, the temperature of the air stream passing through the condenser decreases. The higher the water flow rate, the more air temperature decrease.

\subsection{Condenser Pressure and Evaporator Pressure at Different Evaporative Cooling Flow Rates}

The application of evaporative cooling to air conditioning system reduces the condenser and evaporator pressure during experiments. As indicated in Figure 4(a), the condenser pressure without EC (cooling load of $0 \mathrm{~W}$ ) has an average pressure of 204.5 Psi. The condenser pressure without EC (cooling load of $2000 \mathrm{~W}$ ) has an average pressure of $217.08 \mathrm{Psi}$. The condenser with EC with flow rate of $880 \mathrm{~mL} / \mathrm{min}, 1040 \mathrm{~mL} / \mathrm{min}$, and $1200 \mathrm{~mL} / \mathrm{min}$, have average pressure of $211.46 \mathrm{Psi}, 210$ Psi, and 207.7 Psi, respectively. The use of flow rates ranging from $880 \mathrm{~mL} / \mathrm{min}-1200 \mathrm{~mL} / \mathrm{min}$ can reduce the condenser pressure of $2.7 \%-4.3 \%$.

Similarly, the increase of evaporative cooling water flow rates from $880 \mathrm{~mL} / \mathrm{min}-1200 \mathrm{~mL} / \mathrm{min}$ resulted in the decrease of evaporator pressures as shown in Figure 4(b).

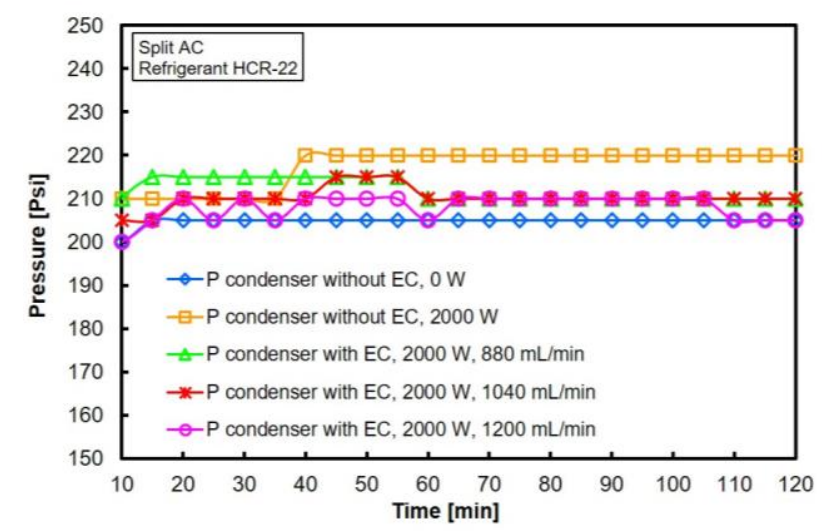

(a)

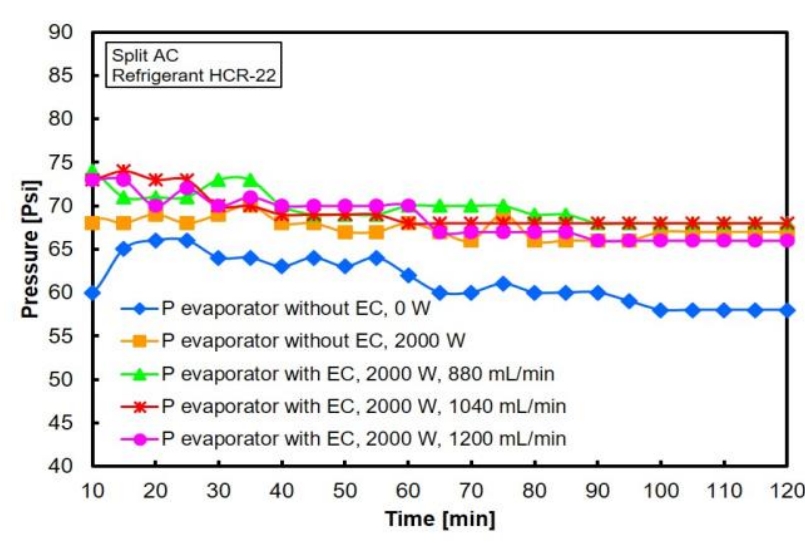

(b)

Fig. 4. Pressures of air conditioning with and without evaporative cooling at different flow rates, (a) condenser, (b) evaporator

\subsection{The Effect of Evaporative Cooling Application and Mass Flow Rates on Condenser and Evaporator Heat Capacity}

To investigate the effect of evaporative cooling on evaporator and condenser heat capacity, a set of calculation results of heat absorption and air conditioning heat rejection with EC (AC with EC) compared to conventional air conditioning ( $A C$ without $E C$ ) were plot in Figure 5 . As shown in Figure 5 , the AC with EC by the flow rate of $880 \mathrm{~mL} / \mathrm{min}$ has a heat rejection capacity of $4,3 \mathrm{~kW}$. This result is higher than conventional AC systems, which reject heat an average $4.24 \mathrm{~kW}$. Comparing to higher flowrate, the heat rejection increases at a higher flow rate. Indicating that the heat is transferred to evaporate water in the cooling pad. Similarly, the flow rate increases evaporator heat capacity. As shown in Figure 5, $1200 \mathrm{~mL} / \mathrm{min}$ 's flow rate has the highest cooling capacity compared to that of 1040 and $800 \mathrm{~mL} / \mathrm{min}$ flow rates. 


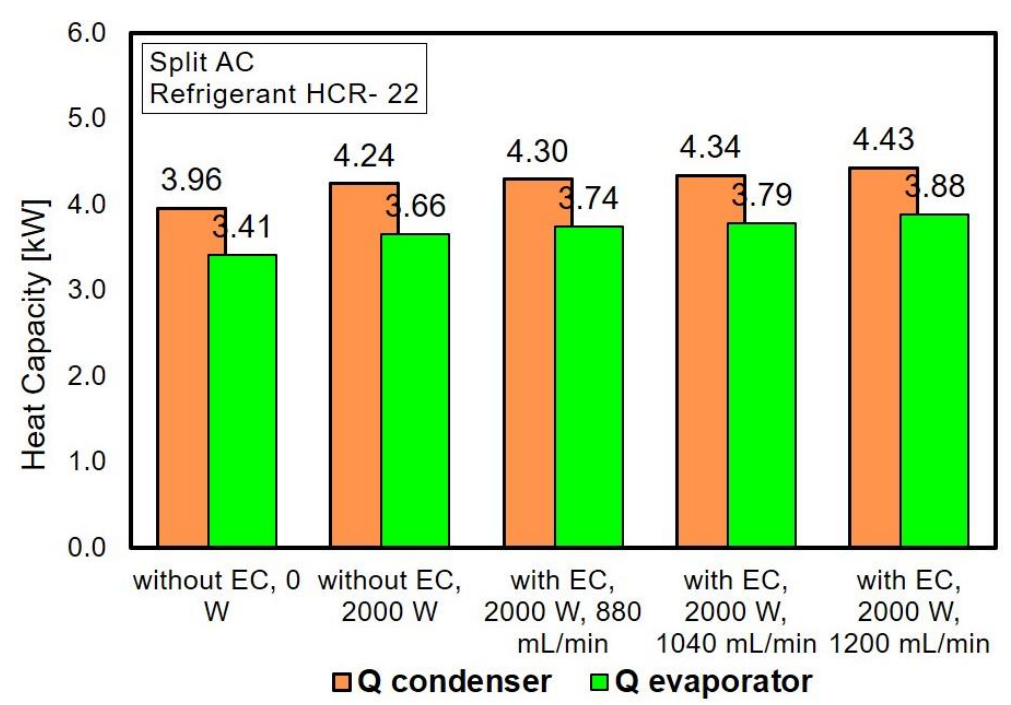

Fig. 5. Heat capacity of condenser and evaporator of split AC with evaporative cooling at different flow rates

\subsection{The Compressor Work and Energy Saving of Evaporative Cooling Application}

The effect of evaporative cooling flow rates on compressor power consumption and the energy saving is described in Figure 6(a). The compressor work of AC without EC ( $0 \mathrm{~W}$ cooling load) is 0.54 $\mathrm{kW}$, and the compressor work of AC without EC ( $2000 \mathrm{~W}$ cooling load) is $0.59 \mathrm{~kW}$. The application of EC could decrease the compressor power consumption. The increase of evaporative cooling flow rate from $880 \mathrm{~mL} / \mathrm{min}, 1040 \mathrm{~mL} / \mathrm{min}$, and $1200 \mathrm{~mL} / \mathrm{min}$ leads to the decrease of power needed by air conditioner for cooling. The compressor works of split air conditioning with evaporative cooling extension are $0.55,0.55$, and $0.54 \mathrm{~kW}$ for water flow rates of $880,1040,1200 \mathrm{~mL} / \mathrm{min}$, respectively.

Figure $6(\mathrm{~b})$ shows the average energy saving percentage of the AC with EC. Here, the compressor work reduces by $5.37 \%, 5.98 \%$, and $6.57 \%$ for flow rate of $880 \mathrm{~mL} / \mathrm{min}, 1040 \mathrm{~mL} / \mathrm{min}$, and 1200 $\mathrm{mL} / \mathrm{min}$ compared to AC without EC at the same cooling load of $2000 \mathrm{~W}$. It is indicated that, the use of EC reduces the compressor work.

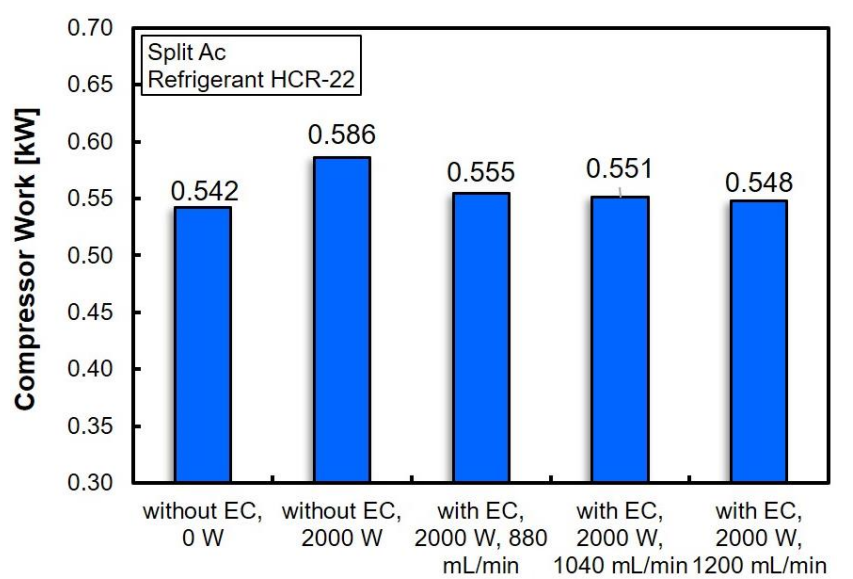

(a)

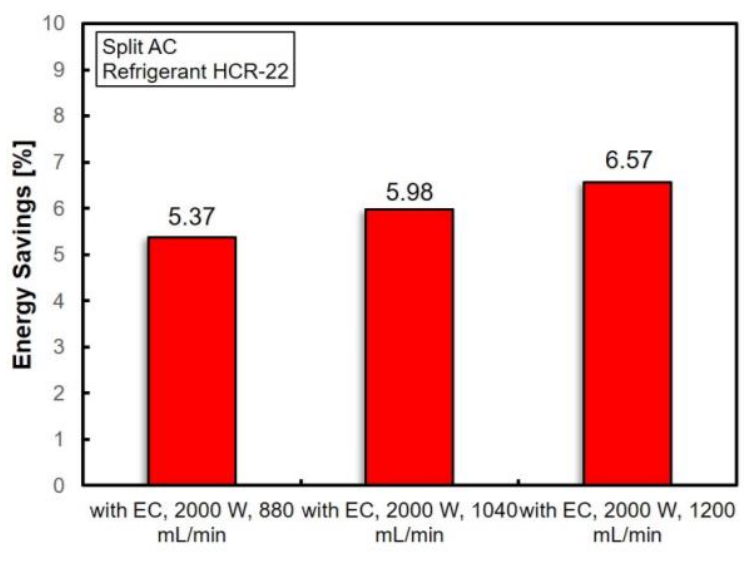

(b)

Fig. 6. The compressor work and energy saving of evaporative cooling application, (a) compressor work, (b) energy saving 


\subsection{The Coefficient of Performance (COP) and COP Increase Percentage}

The COP of refrigeration of split AC with EC application increases compared to without evaporative cooling due to significant amount of water vaporize with absorbed heat from air stream at condenser. Thus, the temperature and pressure of condenser decrease and change the performance of the systems. The COP of the systems is shown at Figure 7(a).

The Figure 7(b) shows the enhancement of COP about $7.44 \%, 9.44 \%$, and $12.95 \%$ at the evaporative cooling application with the flowrate of $880 \mathrm{~mL} / \mathrm{min}, 1040 \mathrm{~mL} / \mathrm{min}$, and $1200 \mathrm{~mL} / \mathrm{min}$.

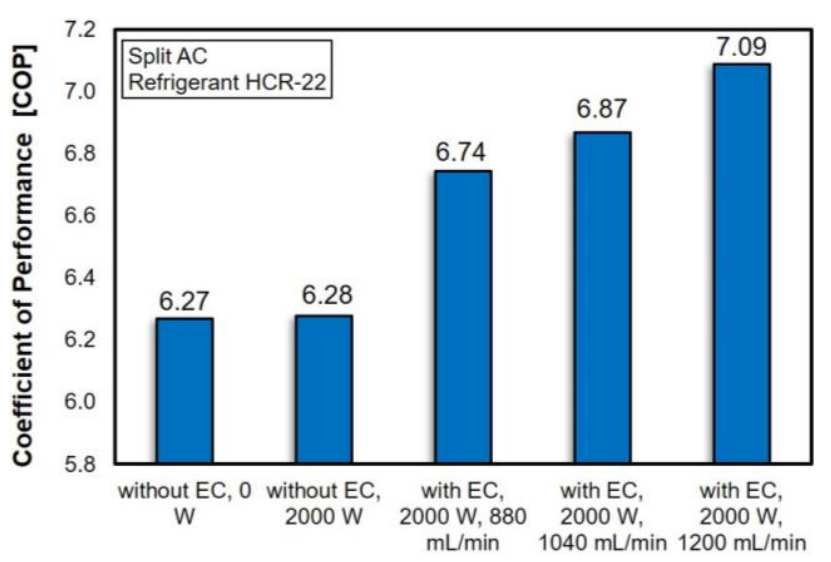

(a)

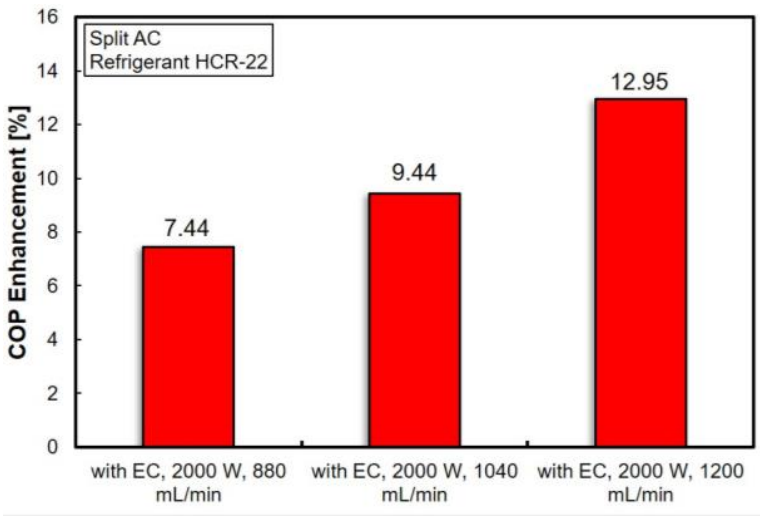

(b)

Fig. 7. COP of split AC with evaporative cooling at different flow rates, (a) COP, (b) COP enhancement

\section{Conclusions}

The comparison performance of evaporative cooling air conditioning system with conventional air conditioning system have been carried out. Three different cooling water flow rates were used for obtaining the efficiency of energy saved. The result shows that by utilizing evaporative cooling could increase the COP of split air. Where the best flow rate that give the best COP is $1200 \mathrm{~mL} / \mathrm{min}$ with COP of 7.09. The compressor work reduces about $6.57 \%$ as compared with the air conditioner without evaporative cooling application. Besides, the COP increase by $12.95 \%$ at the highest flow rate.

\section{Acknowledgement}

Authors thanks to Ministry of Research, Technology and Higher Education of Indonesia for funding this research (Grant number: 095/SP2H/LT/DRPM/IV/2017).

\section{References}

[1] Jahangeer, K. A., Andrew AO Tay, and Md Raisul Islam. "Numerical investigation of transfer coefficients of an evaporatively-cooled condenser." Applied Thermal Engineering 31, no. $10 \quad$ (2011): 1655-1663. https://doi.org/10.1016/i.applthermaleng.2011.02.007

[2] Islam, M. R., K. A. Jahangeer, and K. J. Chua. "Experimental and numerical study of an evaporatively-cooled condenser of air-conditioning systems." Energy 87 (2015): 390-399. https://doi.org/10.1016/i.energy.2015.05.005

[3] Kuki, Ákos, Lajos Nagy, Miklós Zsuga, and Sándor Kéki. "Fast identification of phthalic acid esters in poly (vinyl chloride) samples by direct analysis in real time (DART) tandem mass spectrometry." International Journal of Mass Spectrometry 303, no. 2-3 (2011): 225-228. https://doi.org/10.1016/j.ijms.2011.02.011

[4] Yang, Hua, Na Pei, Liansheng Liu, Man Fan, and Yue Qin. "Experimental study on the effect of condensate water on the performance of split air conditioning system." Energy Reports 7 (2021): 840-851. https://doi.org/10.1016/i.egyr.2021.01.037

[5] Aziz, Azridjal, Rahmat Iman Mainil, Afdhal Kurniawan Mainil, and Hendra Listiono. "Effect of water temperature 
and air stream velocity on performance of direct evaporative air cooler for thermal comfort." In AIP Conference Proceedings, vol. 1788, no. 1, p. 030024. AIP Publishing LLC, 2017. https://doi.org/10.1063/1.4968277

[6] Aziz, A., A. Samri, R. I. Mainil, and A. K. Mainil. "Performance of air source air conditioning water heater using trombone coil dummy condenser with different diameter and pipe length." Journal of Mechanical Engineering and Sciences 14, no. 2 (2020): 6743-6752. https://doi.org/10.15282/jmes.14.2.2020.16.0528

[7] Aziz, Azridjal, Rahmat Iman Mainil, Afdhal Kurniawan Mainil, and Eko Saputra. "Experimental evaluation on the use of capillary tube and thermostatic expansion valve with heat recovery hot spot water heater in air source refrigeration system." In AIP Conference Proceedings, vol. 1788, no. 1, p. 030023. AIP Publishing LLC, 2017. https://doi.org/10.1063/1.4968276

[8] Saengsikhiao, Piyanut, Juntakan Taweekun, Kittinan Maliwan, Somchai Sae-ung, and Thanansak Theppaya. "Improving Energy Efficiency in the Supermarket by Retrofitting Low E Glass Doors for Open Refrigerated." Journal of Advanced Research in Applied Sciences and Engineering Technology 20, no. 1 (2020): 11-17. https://doi.org/10.37934/araset.20.1.1117

[9] Budiyanto, Muhammad Arif, and Nadhilah Suheriyanto. "Analysis of the Effect of Inlet Velocity on Cooling Speed in a Refrigerated Container using CFD simulations." CFD Letters 12, no. 12 (2020): 55-62. https://doi.org/10.37934/cfdl.12.12.5562

[10] Yu, F. W., W. T. Ho, K. T. Chan, R. K. Y. Sit, and J. Yang. "Economic analysis of air-cooled chiller with advanced heat rejection." International Journal of Refrigeration 73 (2017): 54-64. https://doi.org/10.1016/j.ijrefrig.2016.09.016

[11] Aglawe, K. R., M. S. Matey, and N. P. Gudadhe. "Experimental analysis of window air conditioner using evaporative cooling." International Journal of Engineering Research \& Technology 2 (2013): 1-6.

[12] K. Sharma and R. L. Gupta. "Performance Improvement of Air Conditioning System using Applications of Evaporative Cooling: A Review Paper." International Journal of Thermal Engineering 2, no.(2016): 1-5. https://doi.org/10.14445/23950250/IJTE-V2I5P101

[13] Cengel, Yunus A., Michael A. Boles, and Mehmet Kanoglu. Thermodynamics: an engineering approach. Vol. 5. New York: McGraw-hill, 2011.

[14] Alahmer, Ali. "Thermal analysis of a direct evaporative cooling system enhancement with desiccant dehumidification for vehicular air conditioning." Applied Thermal Engineering 98 (2016): 1273-1285. https://doi.org/10.1016/i.applthermaleng.2015.12.059

[15] Kabeel, A. E., Mohamed Abdelgaied, Ravishankar Sathyamurthy, and T. Arunkumar. "Performance improvement of a hybrid air conditioning system using the indirect evaporative cooler with internal baffles as a pre-cooling unit." Alexandria Engineering Journal 56, no. 4 (2017): 395-403. https://doi.org/10.1016/j.aej.2017.04.005

[16] Eidan, Adel A., Kareem J. Alwan, Assaad AlSahlani, and Mohamed Alfahham. "Enhancement of the performance characteristics for air-conditioning system by using direct evaporative cooling in hot climates." Energy Procedia 142 (2017): 3998-4003. https://doi.org/10.1016/i.egypro.2017.12.311

[17] MARTínEZ, Pedro, J. Ruiz, C. G. Cutillas, P. J. Martínez, A. S. Kaiser, and M. Lucas. "Experimental study on energy performance of a split air-conditioner by using variable thickness evaporative cooling pads coupled to the condenser." Applied Thermal Engineering $105 \quad$ (2016): 1041-1050. https://doi.org/10.1016/j.applthermaleng.2016.01.067

[18] Guan, Lisa, Michael Bennett, and John Bell. "Evaluating the potential use of direct evaporative cooling in Australia." Energy and Buildings 108 (2015): 185-194. https://doi.org/10.1016/i.enbuild.2015.09.020

[19] Harby, K., Doaa R. Gebaly, Nader S. Koura, and Mohamed S. Hassan. "Performance improvement of vapor compression cooling systems using evaporative condenser: An overview." Renewable and sustainable energy reviews 58 (2016): 347-360. https://doi.org/10.1016/i.rser.2015.12.313

[20] Yang, Hua, Lan Rong, Xuanchen Liu, Liansheng Liu, Man Fan, and Na Pei. "Experimental research on spray evaporative cooling system applied to air-cooled chiller condenser." Energy Reports 6 (2020): 906-913. https://doi.org/10.1016/i.egyr.2020.04.001

[21] Ulpiani, Giulia. "Water mist spray for outdoor cooling: A systematic review of technologies, methods and impacts." Applied Energy 254 (2019): 113647. https://doi.org/10.1016/j.apenergy.2019.113647

[22] Hajidavalloo, Ebrahim. "Application of evaporative cooling on the condenser of window-air-conditioner." Applied Thermal Engineering 27, no. 11-12 (2007): 1937-1943. https://doi.org/10.1016/i.applthermaleng.2006.12.014

[23] Hajidavalloo, E., and H. Eghtedari. "Performance improvement of air-cooled refrigeration system by using evaporatively cooled air condenser." International journal of refrigeration 33, no. 5 (2010): 982-988. https://doi.org/10.1016/i.ijrefrig.2010.02.001

[24] Sarntichartsak, Pongsakorn, and Sirichai Thepa. "Modeling and experimental study on the performance of an inverter air conditioner using R-410A with evaporatively cooled condenser." Applied Thermal Engineering 51, no. 1-2 (2013): 597-610. https://doi.org/10.1016/j.applthermaleng.2012.08.063

[25] Wang, Tianwei, Chenguang Sheng, and AG Agwu Nnanna. "Experimental investigation of air conditioning system 
using evaporative cooling condenser." Energy and buildings $81 \quad$ (2014): $435-443$. https://doi.org/10.1016/i.enbuild.2014.06.047

[26] Vanbeveren, Stefan PP, Raffaele Spinelli, Mark Eisenbies, Janine Schweier, Blas Mola-Yudego, Natascia Magagnotti, Mauricio Acuna, Ioannis Dimitriou, and Reinhart Ceulemans. "Mechanised harvesting of short-rotation coppices." Renewable and Sustainable Energy Reviews $76 \quad$ (2017): 90-104. https://doi.org/10.1016/i.rser.2017.02.059

[27] P. R. Indonesia. "Presiden republik indonesia." Peratur. Pres. Republik Indones. Nomor 5 Tahun 2006 Tentang Kebijak. ENERGI Nas. 5, (2006).

[28] Ibrahim, Nasiru I., Abdulghani A. Al-Farayedhi, and P. Gandhidasan. "Experimental investigation of a vapor compression system with condenser air pre-cooling by condensate." Applied Thermal Engineering 110 (2017): 1255-1263. https://doi.org/10.1016/i.applthermaleng.2016.09.042

[29] Licina, Dusan, and Chandra Sekhar. "Energy and water conservation from air handling unit condensate in hot and humid climates." Energy and Buildings 45 (2012): 257-263. https://doi.org/10.1016/i.enbuild.2011.11.016

[30] Vakiloroaya, Vahid, Bijan Samali, and Kambiz Pishghadam. "A comparative study on the effect of different strategies for energy saving of air-cooled vapor compression air conditioning systems." Energy and Buildings 74 (2014): 163172. https://doi.org/10.1016/i.enbuild.2014.01.042

[31] Aziz, Azridjal, Thalal Thalal, and Afdhal Kurniawan Mainil. "Effect of Cooling Load on the Performance of R22 Residential Split Air Conditioner when Retrofitted with Hydrocarbon Refrigerant (HCR22)." Journal of Advanced Research in Fluid Mechanics and Thermal Sciences 48, no. 1 (2018): 100-108.

[32] Aziz, A., and A. K. Mainil. "Performance comparison of a refrigerator system using R134a and hydrocarbon refrigerant (HCR134a) with different expansion devices." In IOP Conference Series: Materials Science and Engineering, vol. 237, no. 1, p. 012008. IOP Publishing, 2017. https://doi.org/10.1088/1757-899X/237/1/012008

[33] Aziz, Azridjal, Arya Bhima Satria, and Rahmat Iman Mainil. "Experimental study of split air conditioner with and without trombone coil condenser as air conditioning water heater." International Journal of Automotive and Mechanical Engineering (IJAME) 12, (2015): 3043-3057. https://doi.org/10.15282/ijame.12.2015.18.0253 